\title{
MODERN MARKETING TECHNIQUES ACT AS A CATALYST FOR THE SELLING ACTIVITIES OF AN ENTREPRENEUR: AN INVESTIGATION OF BAKERY AND CONFECTIONERY BUSINESS IN DISTRICT MALIR, KARACHI, PAKISTAN
}

\author{
Muhammad Siddique \\ Research Scholar, Pakistan Navy School of Logistics, PNS Karsaz, Karachi, Pakistan \\ Dr. Abu Zar Wajidi \\ Ph.D. Professor (Meritorious), Research Supervisor, Dean, Barrett Hodgson University, \\ Karachi, Pakistan \\ Dr Mariya Baig \\ Assistant Registrar, ASRB Section, University of Karachi, Pakistan

\section{Dr. Syed Shahid Zaheer Zaidi**} \\ Chairman Department of Public Administration, University of Karachi, Pakistan

\section{Dr. Najabat Ali*} \\ Postdoctoral Candidate, School of Finance and Economics, Jiangsu University, \\ Zhenjiang, China \\ *Corresponding Author/ Co-Supervisor**
}

\begin{abstract}
The part which entrepreneurs play in the economic growth of any country needs no elucidation. Having started new businesses- by utilizing their skills and knowledgethey give proliferation to new ideas in the market and reach the right decisions that serve as vehicles of prosperity and enhancement of the business. The global quest for achieving permanence in economic development and acceleration of social progress has found a new light in entrepreneurial activities. A lot of proponents such as burgeoning urbanization and industrialization, coupled with the prevalence of social legislation as well as general awareness and entrepreneurial education on formal grounds have set the stage for the ever-increasing omnipresence of novel entrepreneurial ventures in various economies across the globe. This study emphasizes the need for modern marketing techniques, which are also an alternative
\end{abstract}


conceptualization of entrepreneurial marketing, which portend a positive influence on the performance of entrepreneurial businesses. Employing a well-developed and verified scale, data collection from 150 respondents was done on a convenience basis (a non-probability data collection method). All of the respondents amongst whom the questionnaires were distributed were based in different areas of district Malir of Karachi and descriptive statistics were applied on the relevant variables such as the importance of advertisement whether they are on electronic media or by print media, for business promotion, use of publicity for sales improvement, similarly, use of other marketing techniques such as sales promotion, personal selling, direct marketing activities, use of SMS marketing and use of social media activities for enhancement of sales as the modern marketing techniques. This research article aims at contributing to the existing academic literature present on the importance of employing modern marketing techniques available at hand to the entrepreneurs involved in the bakery and confectionary businesses across the District Malir of Karachi, Pakistan. This study shall assist government regulators in making informed decisions while addressing the need and importance of modern marketing techniques for Pakistani entrepreneurs, which shall lead to more effective and well-planned initiatives, which can help not only to improve the performance of entrepreneurial ventures but also to curb and eventually eradicate poverty from Pakistan.

Key words: Entrepreneurs, Modern Marketing Techniques, Entrepreneurship Business, Direct Marketing, Bakery \& Confectionary.

Cite this Article: Muhammad Siddique, Abu Zar Wajidi, Mariya Baig, Syed Shahid Zaheer Zaidi and Najabat Ali, Modern Marketing Techniques Act as a Catalyst for the Selling Activities of an Entrepreneur: An Investigation of Bakery and Confectionery Business in District Malir, Karachi, Pakistan, International Journal of Management, 11(12), 2020, pp 64-80.

http://iaeme.com/Home/issue/IJM?Volume=11\&Issue=12

\section{INTRODUCTION}

Entrepreneurship is a term that shows the activity of setting up a business or businesses, taking on financial risks in the hope of profit. In other words, entrepreneurship is an umbrella term that assimilates under it, an activity that entails discovering, evaluating, and exploiting chances to explore new areas and new arenas for the development of new business which incorporated compete different setup of complete supply chain management both upstream and downstream. Selling activates and competition both are increasing day by day. With the increase of population in any part of the world, the requirement of the things of daily life is also increasing simultaneously. Pakistan is also a populated country and Karachi is a megacity of Pakistan. The census report of 2018 says that the total population of Pakistan is to be about 202 million people and the latest population of the city lights (Karachi) is rising at 5\% per year with a total population of 14.9 million. The population of Malir district is about $2,008,901$ persons. There are many bakery and confectionery businesses in the district Malir, Karachi but most such setups are being undertaken by educated people and they do not know the importance of modern marketing techniques that act as a catalyst for increasing the selling activities in the modern world. Marketing activities are done mostly by SMS marketing or by social media marketing perhaps due to cheap in prices. Other marketing activities that are done by the owners of bakery and confectionery businesses are advertisement by print media, by publicity signboards, by visiting cards, by pamphlets, by banners, sales promotion is done at the small scale, personal selling is almost nil, direct marketing activities that cover e-mails, SMS, and phone marketing, is limited to SMS marketing. 
The ensuing paragraphs narrate the relevant literature that indicated the modern marketing techniques used by various bakers and confectionery entrepreneurs for their businesses. In the $3^{\text {rd }}$ section, the research methodology of the study is discussed followed by the analysis of the results discussion. Ultimately the analysis will lead to the conclusion and hence recommendations will be drawn to add on in the body of knowledge.

Research Background: Nowadays in big cities like Karachi a large number of people have been engaged with bakery and confectionery business. Most of the entrepreneurs start this business without a business background and experience. Secondly, the majority of people associated with this business are illiterate and due to the lack of awareness of using the modern marketing techniques they use simple old methods of marketing in their business that is why it is the utmost need to do research in this field.

Problem Statement: From the data collection process it is known that most of the entrepreneurs who are running bakery and confectionery business are less educated. They are unaware of the proper use of modern marketing techniques for enhancement of sales promotion of their businesses and ultimately they remain unable to achieve their business targets. For educating the entrepreneurs about the significance of using modern marketing techniques in the business proper research is essential for meeting the business requirements.

Research Question: This study will have to find out how bakery and confectionary entrepreneurs can overcome their marketing issues and make their business more profitable. Is it true that the use of modern marketing techniques make an entrepreneurial business profitable?

Objectives of the Study: Primarily, this study has the objective to create awareness among the entrepreneurs to use modern marketing techniques in bakery and confectionary businesses so that they can minimize the marketing issues and can get their business targets easily.

The scope of the Study: The scope of the study is to focus on the marketing issues of entrepreneurship businesses and to point out such marketing problems that must be solved for the success of the business.

The significance of the Study: The study will promote the modern marketing techniques among the bakery and confectionery entrepreneurs which are very necessary for the success of any entrepreneurship business.

The beneficiary of the Study: Bakery and confectionery business is the most popular business in the society. A less educated person can starts this business at initially at a low level and with time, such business may grow if it is properly managed and it is properly promoted through the suitable marketing techniques that is why for sake of better business performance every bakery and confectionery entrepreneur can get benefits from this study.

Limitations: Researchers have done their utmost efforts to include the opinions of the maximum respondents (bakery and confectionary entrepreneurs) to address the maximum marketing issues. The researchers highly depended on respondents' answers. It is observed that respondents or participants are never a hundred percent honest. There may be chances of false or wrong answers.

\section{LITERATURE REVIEW}

The literature review is considered the most necessary part of research because this portion indicates how much work has been done before the current research by different people in the same field (Barisic \& Vujnovic, 2018). It provides the base and background to new researchers. It is indicated in the literature review that the use of modern marketing techniques is the main support for enhancing the entrepreneurial selling activities for any business. According to Hossain \& Rahman (2017) contemporary marketing philosophy defines the 
wants and standards of costumers and society (Vladimirovna, 2017). The old and traditional way of marketing is not encouraged by the contemporary entrepreneurial businesses setups. (Rani \& Sinha, 2016). Rauch \& Hatak (2016) explained that nowadays ecommerce and digital marketing is the way to go for the next era which is quite easier and much for effective than the traditional methods. Rauch \& Hatak (2016) further disclosed that marketing techniques play a helping role in increasing the sales of entrepreneurs. Rani \& Sinha (2016) cited that that regular promotion activities are very much important from the maker to the buyer for any entrepreneurial business (Alauddin \& Chowdhury, 2015).

Venkateswarlu \& Ravindra (2015) explained that the use of Integrated Marketing Communication (IMC) tools have a significant impact on the selling activities of an entrepreneur. Robert Blackburn \& Smallbone (2014) pointed out that advertising plays a very positive role in the enhancement of entrepreneurial sales. Kritikos (2014) reported that modern marketing techniques are very essential for entrepreneurial business. Bettinelli et al., (2014) expressed that effective business promoting ideas are delivered by modern marketing techniques. Sebikari (2014) had found that small and medium entrepreneurs have no marketing facility. Ahammad \& Moudud-Ul- Huq (2013) clarified that the most common method is publicizing and advancement. In this regard print media, Television and radio are very useful in attracting the customers. (Rahnama \& Beiki, 2013). Printing fliers are more affordable which can be sent to forthcoming clients (Osotimehin et al., 2012). A TV or radio station may participate in marketing activities of an entrepreneur's marketing activities (Ionit, 2012). Hebert \& Link (2011) studied that progressive sponsoring gadgets cover an objective market, client needs and benefit. Abdullah \& Ahcene, (2011) expressed that the use of present apparatuses of advertising in the interest of the current time because the application of automated broadcasting has prolonged and the influence of encouraging whether it is through print media or by electronic media it makes the positive consequences for making a business concert (Adeniyi, 2011). The facts approve that promotion makes an attention in an item and accelerates the proposals of a business enterprise. Kraus et al., (2010) studied and found that for an entrepreneurial business modern marketing techniques act as the lifeblood for such business in increasing the selling activities. Wadhwani \& Jones (2006) revealed that absence of capitals for advertising and commercials of the products are thoughtful monetary difficulties in the study area and without proper publicity and advertising of the products the required results may not be achieved. Vergragt (2006) found that for the flourishing of an entrepreneurial business proper modern marketing techniques must be used for enhancing the entrepreneurial selling activities. Wadhwani \& Jones (2006) pointed out that the barricades facing by entrepreneurship corporate such as marketing barriers due to insufficient funds. Vergragt (2006) pointed out that the mainstream of businesspersons are fronting glitches of lack of advertising services and unfavorable market behaviors. Wadhwani \& Jones (2006) explored that the novelty competence of SMEs is one of the exclusive qualities. That is why, sales promotion and personal selling, direct marketing, SMS marketing, and social media marketing not only promote the products but also motivate the consumers and costumers for purchasing such products. In short, the net result of modern marketing activities is to increase the selling activities of an entrepreneur and to increase the demand for new products in the market (Gadde \& Snehota, 2001). 


\section{CONCEPTUAL FRAMEWORK}

Based on the study of relevant articles, the researcher has framed the literature review as under:

Independent Variables

Dependent Variable

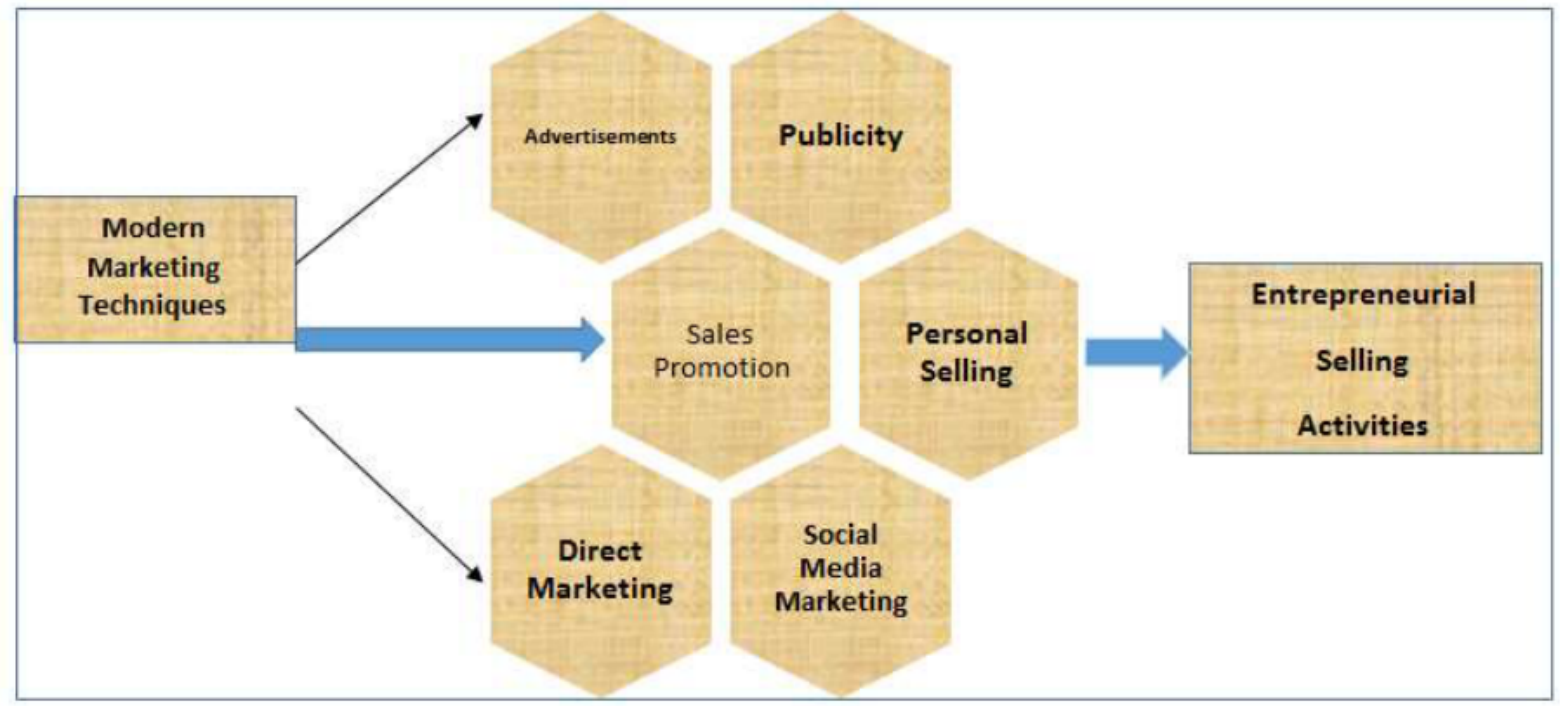

Figure 1 Conceptual Framework

\section{HYPOTHESES}

H1 $1_{0}$ Entrepreneurial selling activities have no positive association with modern marketing techniques.

H1 $1_{\text {A }}$ Entrepreneurial selling activities have a positive association with modern marketing techniques.

\section{Descriptive Analysis of Alternate $\left(\mathrm{H} 1_{\mathrm{A}}\right)$ Hypothesis}

It shows a strong association of entrepreneurial selling activities with the use of modern marketing techniques. It means that as much as an entrepreneur uses modern marketing techniques his volume of sales will increase. Therefore, these techniques act as the catalyst for increasing the sales volume of an entrepreneurial business.

\section{RESEARCH METHODOLOGY}

Population: The population of this study inhabited the bakery and confectionary businesses situated in Saadi Town, Model Colony, Malir Cantt., Shah Faisal Town, Malir Halt and Malir-15, and the relevant areas of District Malir, Karachi.

Sampling Technique: For data collection, the purposive sampling method for convenience was adopted because and data was collected from where it was easy for the researchers. It is the general observation that the people who are less educated and are unaware of the significance of research hesitate to disclose their business and secondly, every entrepreneur did not participate in fulfilling the questionnaire. From a total of 250 questionnaires, only 150 valid questionnaires received back.

Sample Size: A total of 250 questionnaires were distributed among bakery and confectionary units gave them time as per their demand and were requested to complete the structured 
questionnaire voluntarily but only 150 respondents had responded and returned the completed questionnaires. Therefore, 150 respondents are considered a valid sample for this study.

Data Collection Technique and Instrument: A well-structured and verified scale was used to gather statistics for the study. The questionnaires were circulated among the respondents in different areas of Saadi Town, Model Colony, Malir Cantt., Shah Faisal Town, Malir Halt and Malir-15, and the relevant areas of District Malir, Karachi personally by the researchers. The data were taken from bakery and confectionary businesses situated in the sample areas. The majority of bakery and confectionary entrepreneurs were less educated and lacked the use of modern marketing techniques training. The data were collected in 40 days subsequently the collected data was then analyzed by the statistical tools using SPSS.

Reliability Test: In order to check the internal consistency of the tool, Cronbach's alpha was calculated. The rate of Cronbach's Alpha was 0.689 i.e. that is almost equal to 0.70 . It is suggested the accepted edge of reliability should be at least 0.70 . It shows that our tool is reliable.

\section{DATA ANALYSIS AND FINDINGS}

This section covers two parts. Part-A represents the data demographics and Part-B represents the data analysis of the study.

PART-A: Data Demographics: In this part, the demographic section of the respondents has been addressed.

GENDER: This study exclusively consists of 150 confectioners, comprising of 146 male and only 4 female, working in the sample area of Karachi. It is shown in Figure_2, below:

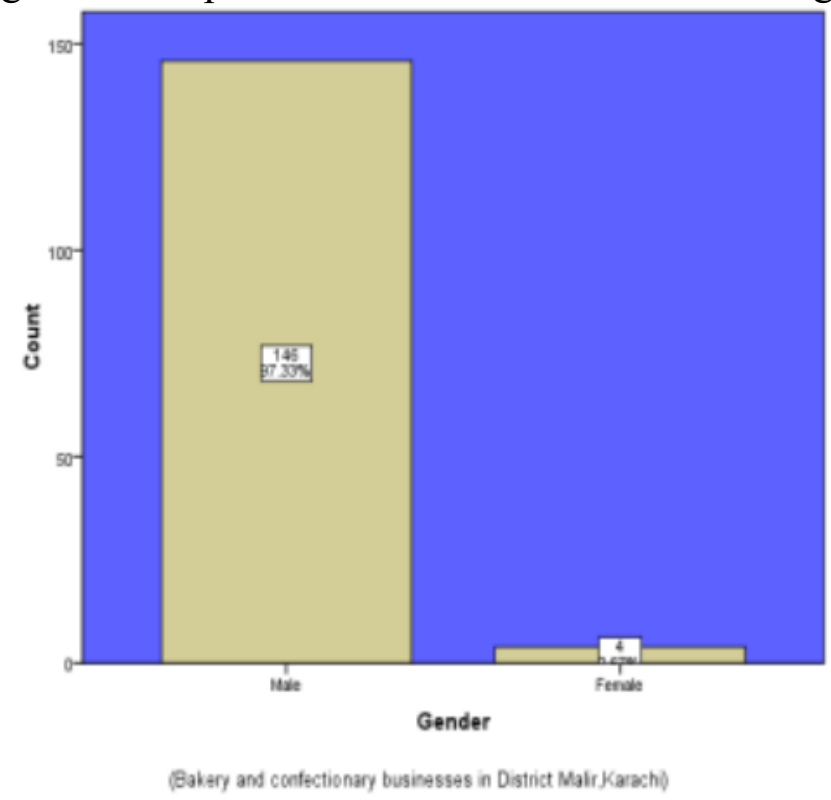

Figure 2 Gender of respondents

AGE: Figure 3, below depicts that from the total 4 persons that comprise $2.67 \%$ of the overall population are in the age group of 22 years, 6 persons covers $4 \%$ of the population, similarly, different age groups represent different percentages of populations and the last person who is of 65 years of age shows $0.7 \%$ of the total population 


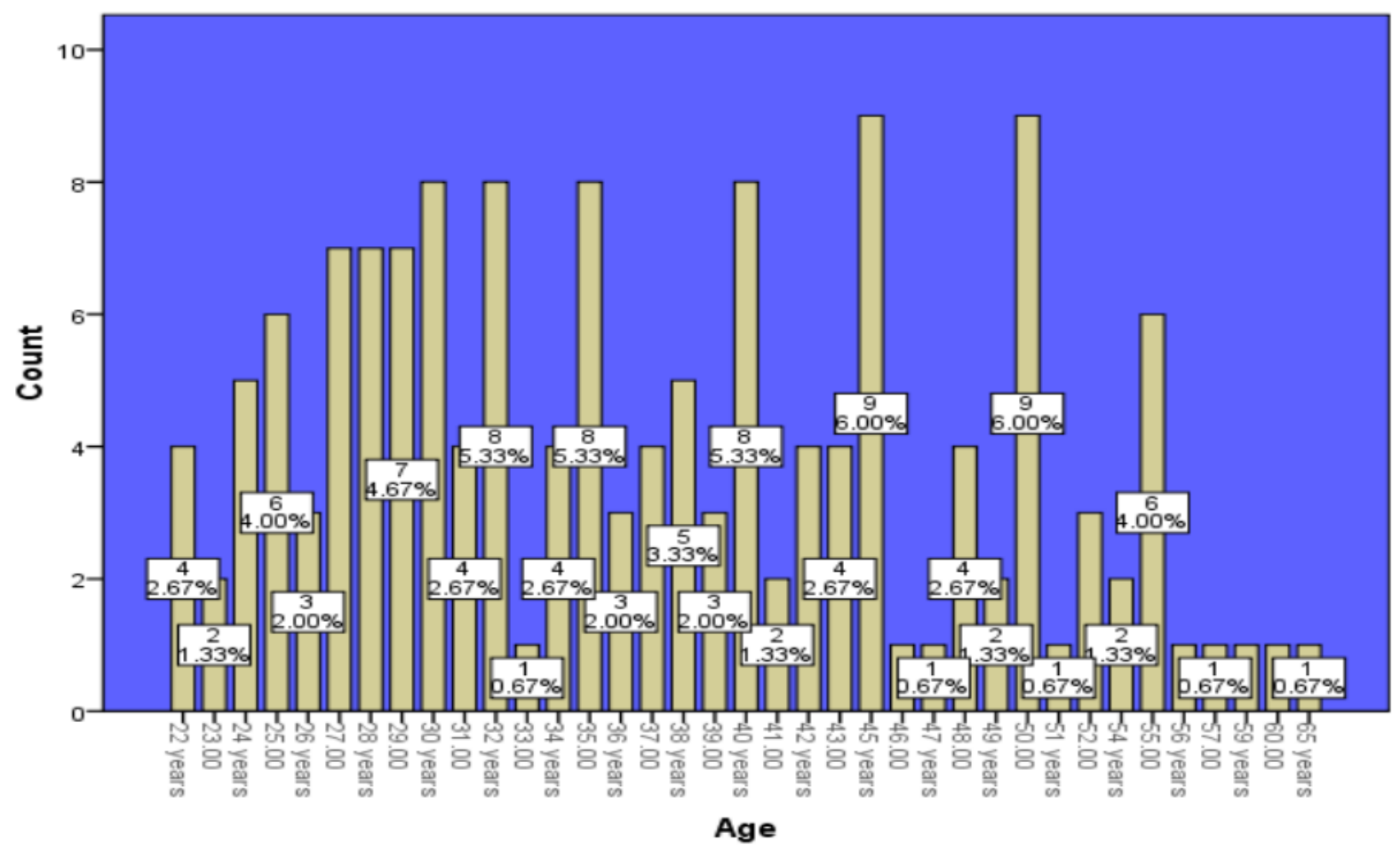

(Bakery and confectionary businesses in District Malir, Karachi)

Figure 3 Age of respondents

EDUCATION: Figure 4 represents the age of respondents. Accordingly, 38 persons were non-matric that showed $25.3 \%$ of the total population, 55 confectioners were the only matric, 29 respondents were intermediate, 25 were graduate and only 3 respondents were postgraduates and of $2 \%$ of the total population was doing the confectionery business in the sample area. It shows that this business needs not higher education, a reasonable education is enough to run this business.

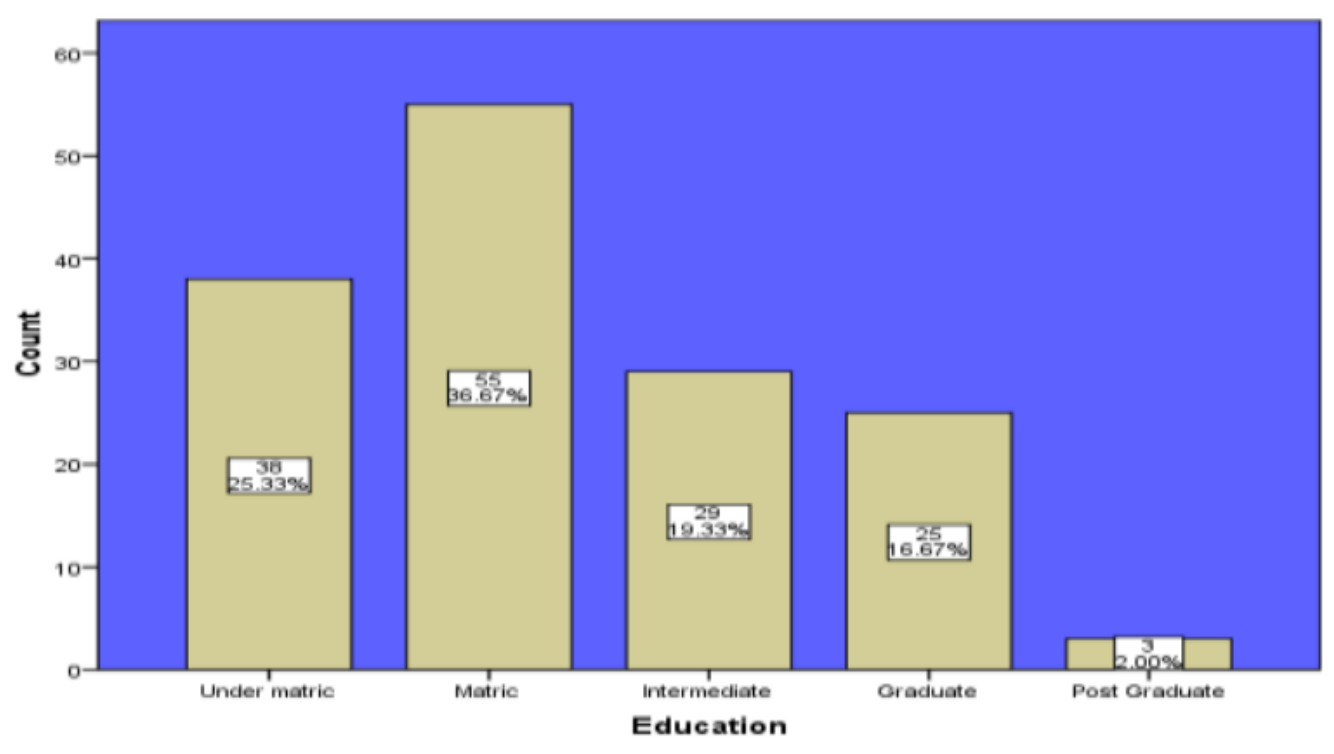

(Bakery and confectionary businesses in District Malir,Karachi)

Figure 4 Education of respondents 
Modern Marketing Techniques Act as a Catalyst for the Selling Activities of an Entrepreneur: An Investigation of Bakery and Confectionery Business in District Malir, Karachi, Pakistan

EXPERIENCE: Figure_5: depicts that only one person has one year experience, while different persons working in the sample area have experiences of confectionary business from lyear to 20 years.

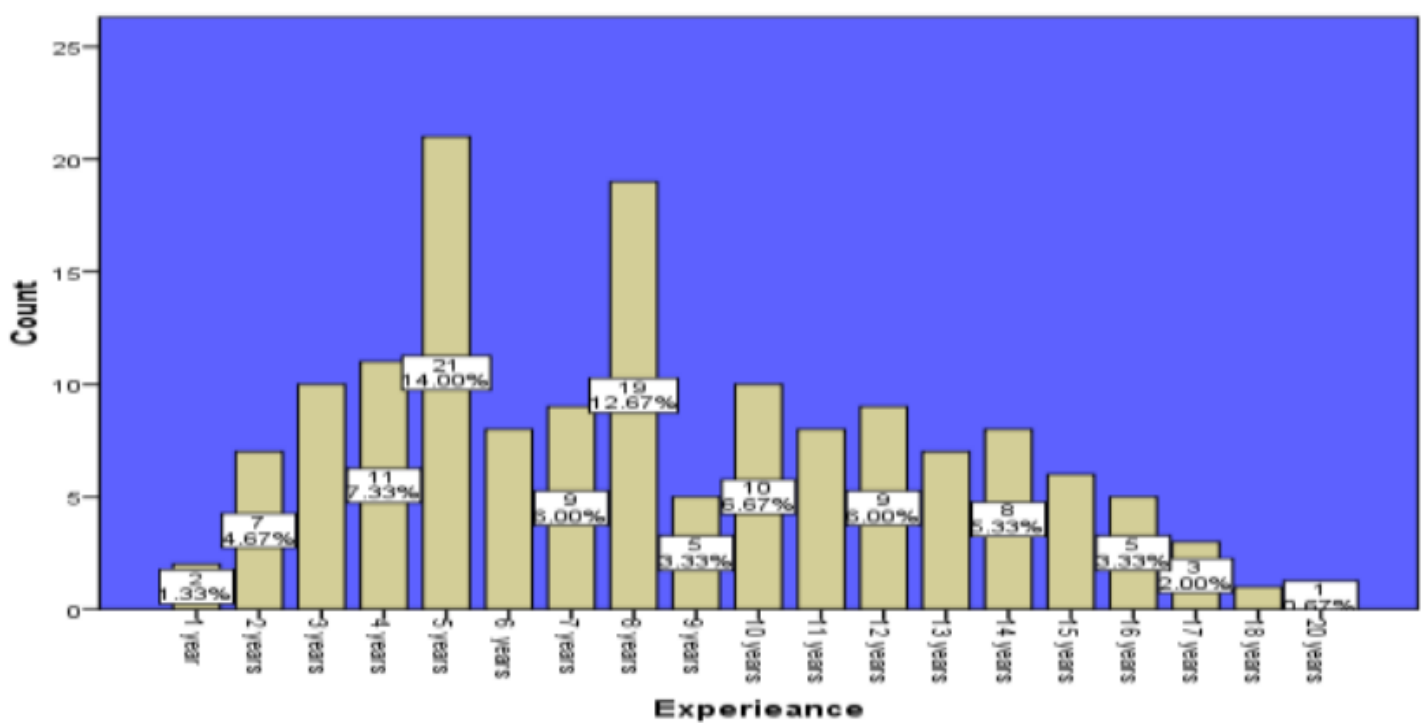

(Bakery and confectionary businesses in District Malir,Karachi)

Figure 5 Experience of respondents

Strength (Number of respondents): A total of 150 confectioners are working in the sample area. The distribution of working persons in different bakery and confectioneries is shown by figure_6, below:

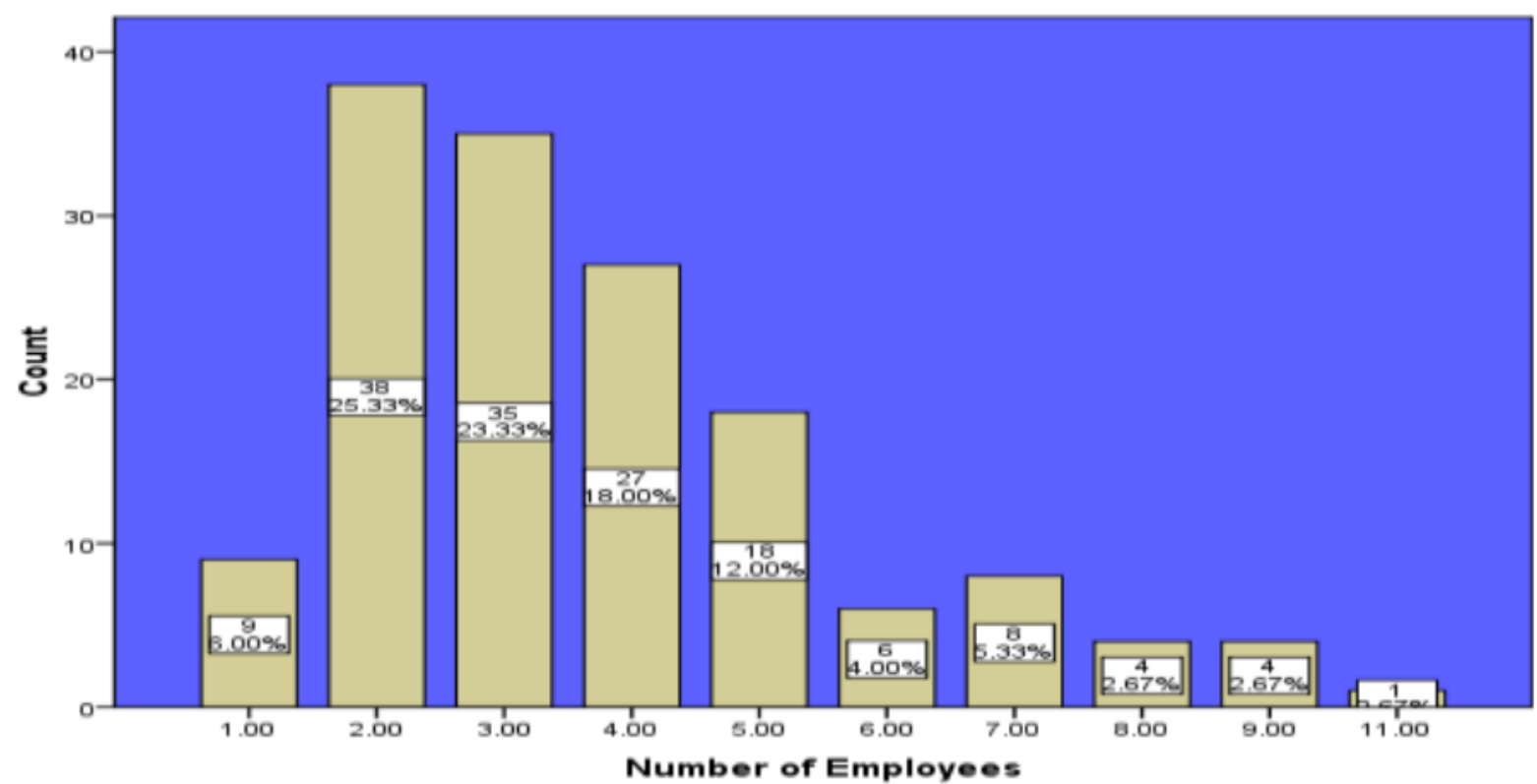

Figure 6 Strength (Number of respondents)

PART-B: DATA ANALYSIS: This section of analysis covers with the help of figures that indicate analysis was done by the Statistical Package for Social Sciences (SPSS) and the resultant results have been discussed accordingly. 
Publicity: Publicity is one of the best ways of sales promotion. Bakers and Confectioners do the publicity of their products through banners, visiting cards, pamphlets, and wall chalking, etc. According to the descriptive analysis of the data gathered from the respondents of the sample population and their results as per Likert scale analysis are shown in figure_7 below. Accordingly, $24.67 \%$ of respondents strongly agreed and $32.67 \%$ of respondents agreed with the alternate hypothesis while $12 \%$ of respondents remained neutral and $0.67 \%$ disagreed with the alternate hypothesis.

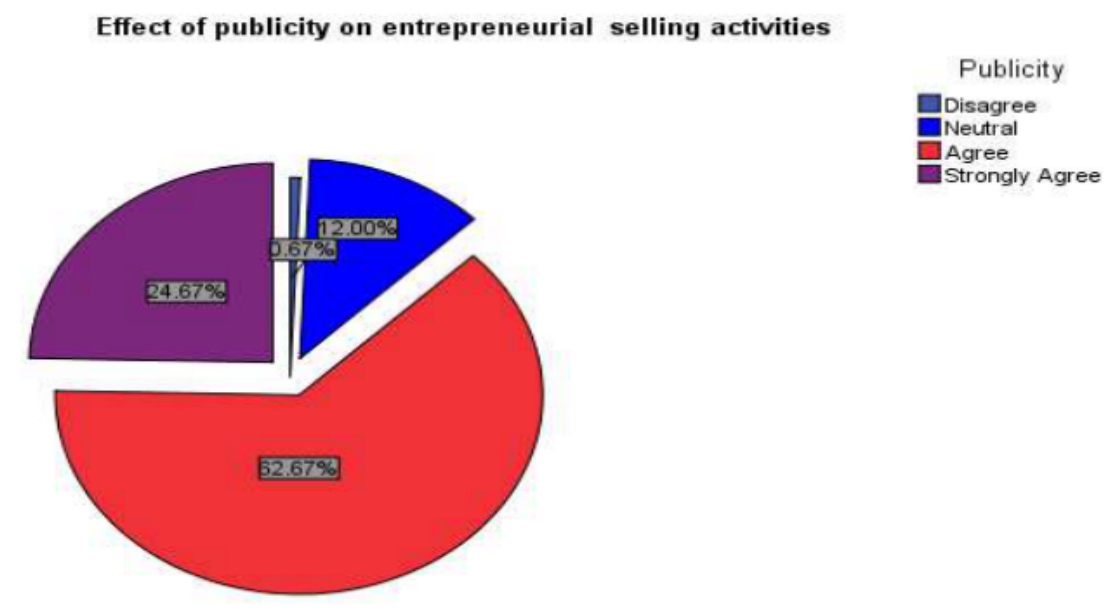

Figure 7

Direct Marketing: Direct marketing is a very useful tool for modern marketing. It is used to inform the valued clients. Bakers and Confectioners use the direct marketing tool frequently to attract customers by SMS-marketing, Email-marketing, and Phone-marketing as per need. According to the descriptive analysis of the data gathered from the respondents of the sample population and their results as per Likert scale analysis are shown in figure 8 below. Accordingly, $56.67 \%$ of respondents strongly agreed and $31.33 \%$ of respondents agreed with the alternate hypothesis while $10 \%$ of respondents remained neutral and $2 \%$ disagreed with the alternate hypothesis.

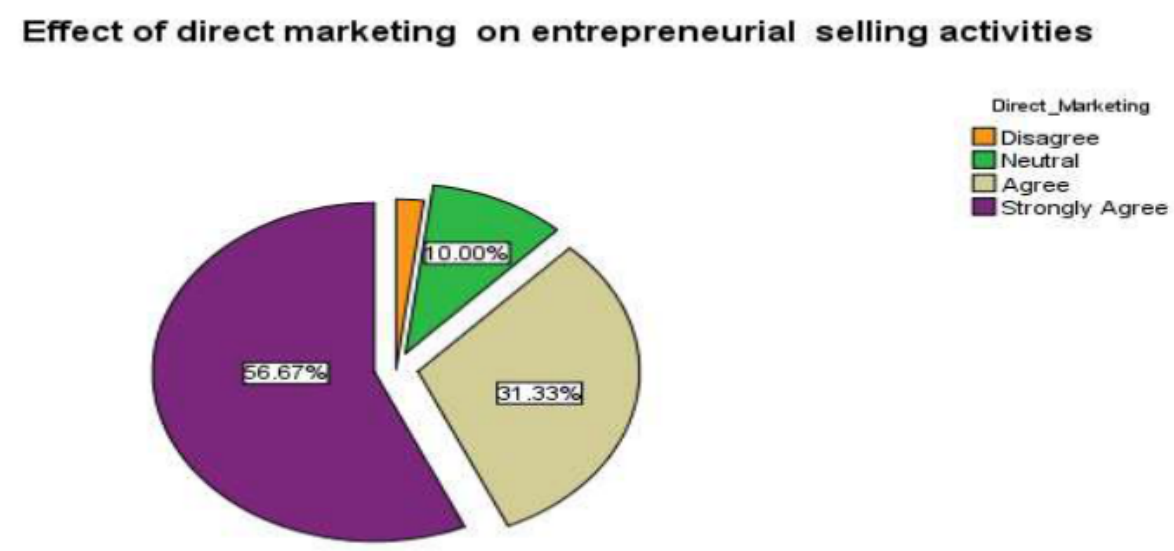

Figure 8 
Sales Promotion: Sometimes, incentive schemes are offered by the bakers and confectioners as a modern marketing tool to attract the customers for getting a competitive advantage. According to the descriptive analysis of the data gathered from the respondents of the sample population and their results as per Likert scale analysis are shown in figure_9 below. Accordingly, $52.00 \%$ of defendants strongly agreed and $23.33 \%$ of respondents agreed with the alternate hypothesis while $10 \%$ of respondents remained neutral and $4.67 \%$ disagreed with the alternate hypothesis.

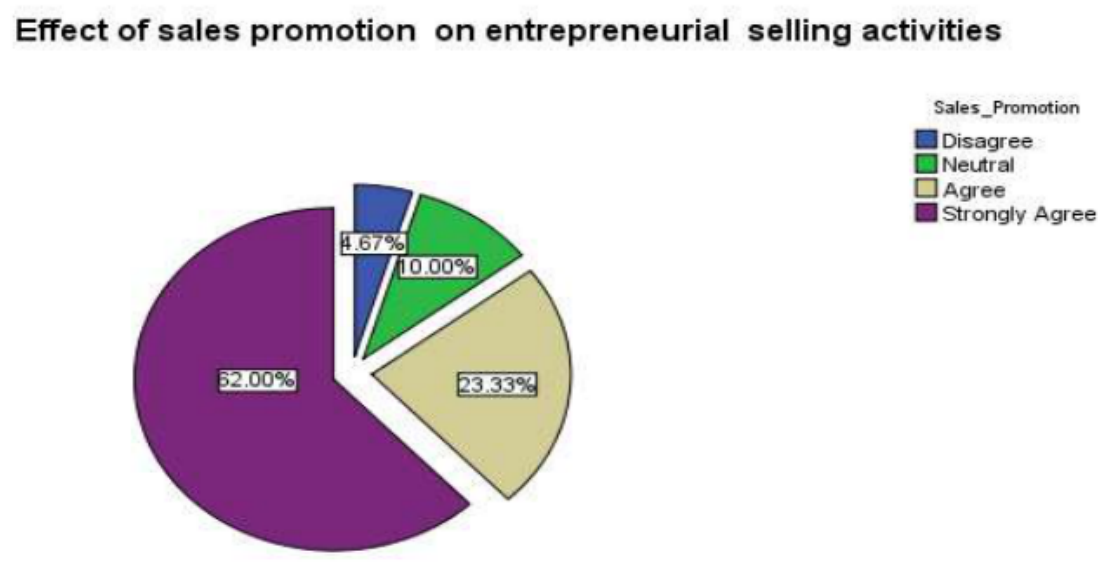

Figure 9

Personal Selling: For selling or introducing the new products in the market, the modern tool of marketing such as personal selling is the best technique. The bakers and confectioners can easily explain the product and answer easily to satisfy the customer and to resolve their queries. According to the descriptive analysis of the data gathered from the respondents of the sample population and their results as per Likert scale analysis are shown in figure_10, below. Accordingly, $30.67 \%$ of respondents strongly agreed and $50.67 \%$ of respondents agreed with the alternate hypothesis while $12 \%$ of respondents remained neutral and $4.67 \%$ disagreed and $2 \%$ strongly disagreed with the alternate hypothesis.

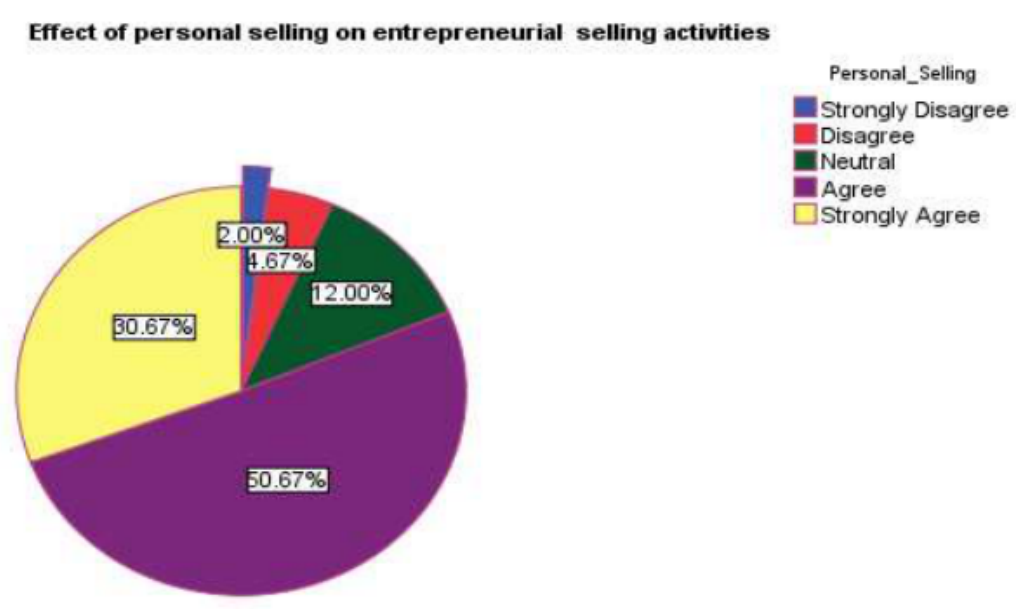

Figure 10 
Social Media: Social media is the latest modern technique of marketing that is used very popularly by bakers and confectioners. It is a cheap way of marketing. According to the descriptive analysis of the data gathered from the respondents of the sample population and their results as per Likert scale analysis are shown in figure_11, below. Accordingly, $36.67 \%$ of respondents strongly agreed and $43.33 \%$ of respondents agreed with the alternate hypothesis while $11.33 \%$ of respondents were unbiassed and $7.33 \%$ disagreed and $1.33 \%$ strongly disagreed with the alternate hypothesis.

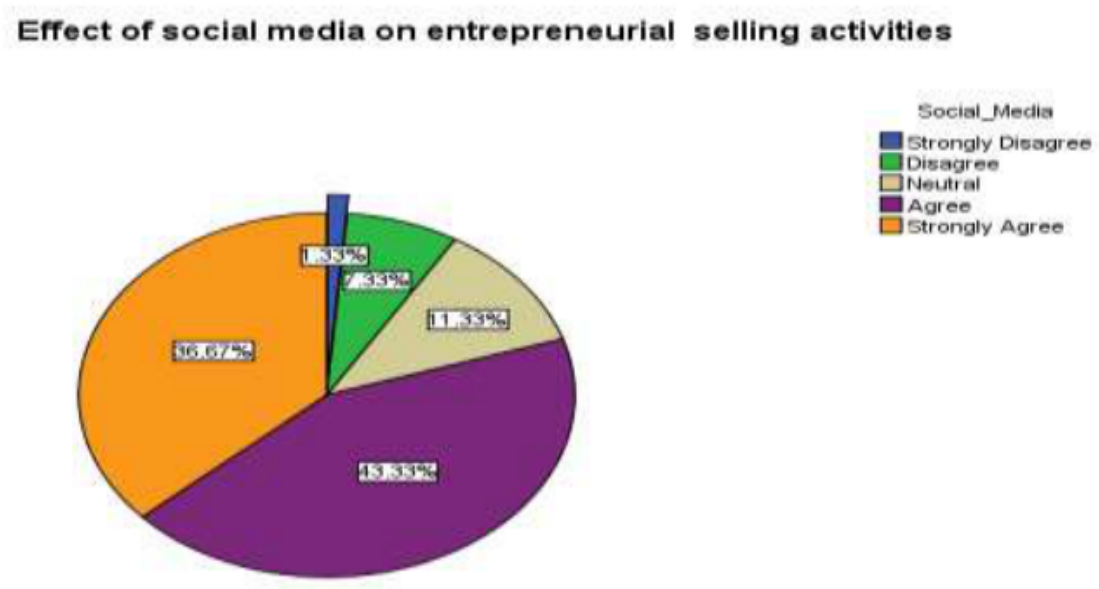

Figure 11

Advertisement: Advertisement, whether it is through electronic or through print media, is a known or famous way of modern marketing to promote the products of an entrepreneur. According to the descriptive analysis of the data gathered from the respondents of the sample population and their results as per Likert scale analysis are shown in figure_12, below. Accordingly, $24.00 \%$ of respondents strongly agreed and $55.33 \%$ of respondents agreed with the alternate hypothesis while $18.67 \%$ of respondents remained neutral and $2.00 \%$ disagreed with the alternate hypothesis.

\section{Effect of advertisement on entrepreneurial selling activities}

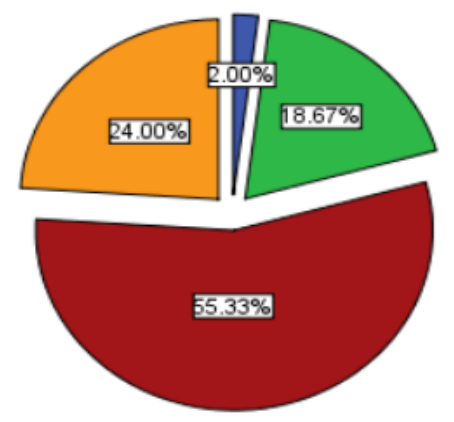




\section{CONCLUSIONS}

Based on data analysis and discussion it is concluded that for improvement in sales volume of a baker \& confectioner must use the modern tools of marketing as discussed below:

1. Publicity:

The bakers and confectioners do the publicity of their products through banners, visiting cards, pamphlets, and wall chalking, etc. It is a suitable way of promotion due to its cheapness and easy way of promotion.

2. Direct marketing: It is a very useful tool for modern marketing. It is used to inform the valued clients. Bakers and Confectioners use this tool frequently to attract customers by SMSmarketing, Email-marketing, and Phone-marketing as well.

3. Sales Promotion: In this method, incentive schemes are offered by the bakers and confectioners as a modern marketing tool to attract the customers for getting a competitive advantage. It is an early result-oriented way of marketing techniques.

4. Personal Selling: Especially, for introducing the new products in the market, it is the best technique. In this technique, a person explains the features of the products. The bakers and confectioners can easily explain their products and they may link such products with the consumers' needs.

5. Social Media: Social media is the latest modern technique of marketing that is used very popularly by bakers and confectioners. It is also a very popular and cheap way of marketing.

6. Advertisement: Advertisement is a common way of promotion whether it is through electronic or through print media. It is a very famous way of modern marketing to promote the products of a baker and confectioner.

\section{RECOMMENDATIONS}

The proposed recommendations for the study are:

- Based on the results achieved from the analysis, the application of modern marketing techniques such as publicity, direct marketing, sales promotion, personal selling, social media, and advertisement may be very helpful in achieving the required sales targets of the bakery and confectionery businesses.

- The use of modern marketing techniques are justified to recommend for bakery and confectionery business people are very busy and social gatherings have almost finished and the only way of contact to the customers is the use the modern marketing techniques that may effectively act as the catalyst to increase the sales volume of the bakery and confectionery business especially in the sample area.

\section{REFERENCES}

[1] Abdullah, S., \& Ahcene, L. (2011). The Understanding of Technology Entrepreneurship According to Shariah Principles. International Conference on Business and Economics Research, 16, 144-150.

[2] Adeniyi, A. O. (2011). Comtemporary Marketing Strategies and Performance of Agricultural Maarketing Firms in South- West Nigeria. School of Business, College of Development Studies, Covenant University, OTA, Ogun State, Nigeria.

[3] Ahammad, I., \& Moudud-U1- Huq. (2013). Women Entrepreneurship Development In Bangladesh Challenges And Prospects. International Journal of Innovative Research \& Development, 2(7), 41-48. 
[4] Alauddin, M., \& Chowdhury, M. M. (2015). Small and Medium Enterprise in BangladeshProspects and Challenges. Global Journal of Management and Business Research: C Finance, 15(7), 11.

[5] Barisic, A. F., \& Vujnovic, K. (2018). Attitudes of Entrepreneurs Towards Social Media As a. Education for Entrepreneurship, 8(Special Issue (2018)), 139-154.

[6] Bettinelli, C., Fayolle, A., \& Randerson, K. (2014). Family Entrepreneurship: A Developing Field. Foundations and Trends ${ }^{\circledR}$ in Entrepreneurship, 10(3), 161-236. https://doi.org/10.1561/0300000049

[7] Gadde, L., \& Snehota, I. (2001). Rethinking the Role of Middlemen.

[8] Hebert, R. F., \& Link, A. N. (2011). A History of Entrepreneurship. International Journal of Business and Social Science, 2(9), 241-242.

[9] Hossain, M. S., \& Rahman, M. F. (2017). Tools of online marketing. International Journal of Science and Business, 1(1), 1-7. https://doi.org/10.5281/zenodo.439702

[10] Ionita, Daniela. (2012). Entrepreneurial Marketing: A New Approach Fof Challenging Times. Management \& Marketing Challenges for the Knowledge Society, 7(1), 131-150.

[11] Ionita, David. (2012). Entrepreneurial Marketing: A New Approach For Challenging Times. Management \& Marketing: Challenges for the Knowledge Society, 7(1), 131-150. https://doi.org/10.5295/cdg.100190jg

[12] Kraus, S., Harms, R., \& Fink, M. (2010). Entrepreneurial marketing: Moving beyond marketing in new ventures. International Journal of Entrepreneurship and Innovation Management, 11(1), 19-34. https://doi.org/10.1504/IJEIM.2010.029766

[13] Kritikos, A. S. (2014). Entrepreneurs and their impact on jobs and economic growth. https://doi.org/10.15185/izawol.8

[14] Osotimehin, K. O., Jegede, C. A., Akinlabi, B. H., \& Olajide, O. T. (2012). An Evaluation of the Challenges and Prospects of Micro and Small Scale Enterprises Development in Nigeria. American International Journal of Contemporary Research, 2(4), 174-185.

[15] Rahnama, R., \& Beiki, A. H. (2013). Modern Marketing, Concepts and Challenges. Oman Chapter of Arabian Journal of Business and Management Review, 2(6), 143-155. https://doi.org/10.12816/0002302

[16] Rani, J., \& Sinha, S. K. (2016). Barriers Facing Women Entrepreneurs in Rural India: A Study in Haryana, $1(1)$.

[17] Rauch, A., \& Hatak, I. (2016). A meta-analysis of different HR-enhancing practices and performance of small and medium sized firms. Journal of Business Venturing, 31(5), 485504. https://doi.org/10.1016/j.jbusvent.2016.05.005

[18] Robert Blackburn, \& Smallbone, D. (2014). Sustaining self-employment for disadvantaged entrepreneurs. Retrieved from http://www.oecd.org/cfe/leed/Background paper for sustainability policy brief rev.pdf

[19] Ryota, B. (2013). Entrepreneurship and Human Capital : Empirical study using a survey of entrepreneurs in Japan. The Research Institute of Economy, Trade and Industry, 13-E049(May 2013), 1-26.

[20] Sebikari, K. V. (2014). Entrepreneurial Performance and Small Business Enterprises in Uganda. International Journal of Small Business and Entrepreneurship Research, 2(4), 1-12.

[21] Venkateswarlu, P., \& Ravindra, P. S. (2015). An Empirical Study on Problem and Prospects of Rural Entrepreneurs with Special Reference to Visakhapatnam District. International Journal of Management and Commerce Innovations, 2(2), 458-467.

[22] Vergragt, P. J. (2006). How Technology Could Contribute to a Sustainable World. England. 
Modern Marketing Techniques Act as a Catalyst for the Selling Activities of an Entrepreneur: An Investigation of Bakery and Confectionery Business in District Malir, Karachi, Pakistan

[23] Vladimirovna, S. Y. (2017). Influence of the Marketing Paradigm's Cycles Patterns on the Global Entrepreneurship. Economic and Managerial Spectrum, 11(1), 48-61.

[24] Wadhwani, R. D., \& Jones, G. (2006). Entrepreneurship and Business History: Renewing the Research Agenda. Harvard Business School giones@hbs.edu. California.

[25] Winfrey, O., Medal, P., President, U. S., Obama, B., Ratia, A., \& Branson, S. R. (2013). Entrepreneurship.

\title{
APPENDIXES
}

\author{
RESUSLTS OF CRONBACH'S ALPHA - APPENDIX-A \\ SPSS-FIGURES - APPENDIX-B \\ CLOSED ENDED QUESTIONNAIRES - APPENDIX-C
}

\section{APPENDIX-A}

Table 1: Case Processing Summary

\begin{tabular}{|ll|l|l|}
\hline & & $\mathbf{N}$ & $\%$ \\
\hline Cases & Valid & 150 & 100.0 \\
& Excluded & 0 & 0 \\
& Total & 150 & 100.0 \\
\hline
\end{tabular}

a. List wise deletion based on all variables in the procedure.

Table 2: Reliability Statistics

\begin{tabular}{|l|l|}
\hline $\begin{array}{l}\text { Cronbach's } \\
\text { Alpha }\end{array}$ & N of Items \\
\hline 689 & 12 \\
\hline
\end{tabular}

Table 3: Statistics

\begin{tabular}{|ll|c|c|c|c|c|}
\hline & & Gender & Age & Education & Experience & $\begin{array}{c}\text { Number of } \\
\text { Employees }\end{array}$ \\
\hline & Valid & 150 & 150 & 150 & 150 & 150 \\
& Missing & 0 & 0 & 0 & 0 & 0 \\
Mean & & 1.0267 & 37.4933 & 2.3333 & 8.4067 & 3.7267 \\
Median & 1.0000 & 36.0000 & 2.0000 & 8.0000 & 3.0000 \\
Mode & 1.00 & $45.00^{\mathrm{a}}$ & 2.00 & 5.00 & 2.00 \\
Std. Deviation & .16165 & $1.01106 \mathrm{E} 1$ & 1.09094 & 4.33976 & 1.97941 \\
Minimum & 1.00 & 22.00 & 1.00 & 1.00 & 1.00 \\
Maximum & 2.00 & 65.00 & 5.00 & 20.00 & 11.00 \\
Percentiles & 25 & 1.0000 & 29.0000 & 1.0000 & 5.0000 & 2.0000 \\
& 50 & 1.0000 & 36.0000 & 2.0000 & 8.0000 & 3.0000 \\
& 75 & 1.0000 & 45.0000 & 3.0000 & 12.0000 & 5.0000 \\
\hline
\end{tabular}

a. Multiple modes exist. The smallest value is shown 
Table 4: Gender

\begin{tabular}{|cl|c|c|c|c|}
\hline & Frequency & Percent & Valid Percent & $\begin{array}{c}\text { Cumulative } \\
\text { Percent }\end{array}$ \\
\hline Valid & Male & 146 & 97.3 & 97.3 & 97.3 \\
& Female & 4 & 2.7 & 2.7 & 100.0 \\
& Total & 150 & 100.0 & 100.0 & \\
\hline
\end{tabular}

Table 5: Age

\begin{tabular}{|c|c|c|c|c|c|}
\hline & & Frequency & Percent & Valid Percent & $\begin{array}{c}\text { Cumulative } \\
\text { Percent }\end{array}$ \\
\hline \multirow{38}{*}{ Valid } & 22 & 4 & 2.7 & 2.7 & 2.7 \\
\hline & 23 & 2 & 1.3 & 1.3 & 4.0 \\
\hline & 24 & 5 & 3.3 & 3.3 & 7.3 \\
\hline & 25 & 6 & 4.0 & 4.0 & 11.3 \\
\hline & 26 & 3 & 2.0 & 2.0 & 13.3 \\
\hline & 27 & 7 & 4.7 & 4.7 & 18.0 \\
\hline & 28 & 7 & 4.7 & 4.7 & 22.7 \\
\hline & 29 & 7 & 4.7 & 4.7 & 27.3 \\
\hline & 30 & 8 & 5.3 & 5.3 & 32.7 \\
\hline & 31 & 4 & 2.7 & 2.7 & 35.3 \\
\hline & 32 & 8 & 5.3 & 5.3 & 40.7 \\
\hline & 33 & 1 & .7 & .7 & 41.3 \\
\hline & 34 & 4 & 2.7 & 2.7 & 44.0 \\
\hline & 35 & 8 & 5.3 & 5.3 & 49.3 \\
\hline & 36 & 3 & 2.0 & 2.0 & 51.3 \\
\hline & 37 & 4 & 2.7 & 2.7 & 54.0 \\
\hline & 38 & 5 & 3.3 & 3.3 & 57.3 \\
\hline & 39 & 3 & 2.0 & 2.0 & 59.3 \\
\hline & 40 & 8 & 5.3 & 5.3 & 64.7 \\
\hline & 41 & 2 & 1.3 & 1.3 & 66.0 \\
\hline & 42 & 4 & 2.7 & 2.7 & 68.7 \\
\hline & 43 & 4 & 2.7 & 2.7 & 71.3 \\
\hline & 45 & 9 & 6.0 & 6.0 & 77.3 \\
\hline & 46 & 1 & .7 & .7 & 78.0 \\
\hline & 47 & 1 & .7 & .7 & 78.7 \\
\hline & 48 & 4 & 2.7 & 2.7 & 81.3 \\
\hline & 49 & 2 & 1.3 & 1.3 & 82.7 \\
\hline & 50 & 9 & 6.0 & 6.0 & 88.7 \\
\hline & 51 & 1 & .7 & .7 & 89.3 \\
\hline & 52 & 3 & 2.0 & 2.0 & 91.3 \\
\hline & 54 & 2 & 1.3 & 1.3 & 92.7 \\
\hline & 55 & 6 & 4.0 & 4.0 & 96.7 \\
\hline & 56 & 1 & .7 & .7 & 97.3 \\
\hline & 57 & 1 & .7 & .7 & 98.0 \\
\hline & 59 & 1 & .7 & .7 & 98.7 \\
\hline & 60 & 1 & .7 & .7 & 99.3 \\
\hline & 65 & 1 & .7 & .7 & 100.0 \\
\hline & Total & 150 & 100.0 & 100.0 & \\
\hline
\end{tabular}


Modern Marketing Techniques Act as a Catalyst for the Selling Activities of an Entrepreneur: An Investigation of Bakery and Confectionery Business in District Malir, Karachi, Pakistan

Table 6 Education

\begin{tabular}{|ll|c|c|c|c|}
\hline & Frequency & Percent & Valid Percent & $\begin{array}{c}\text { Cumulative } \\
\text { Percent }\end{array}$ \\
\hline Valid & under matric & 38 & 25.3 & 25.3 & 25.3 \\
& Matric & 55 & 36.7 & 36.7 & 62.0 \\
& Intermediate & 29 & 19.3 & 19.3 & 81.3 \\
& Graduate & 16.7 & 16.7 & 98.0 \\
& Post Graduate & 3 & 2.0 & 2.0 & 100.0 \\
Total & 150 & 100.0 & 100.0 & \\
\hline
\end{tabular}

Table 7 Experience

\begin{tabular}{|c|c|c|c|c|c|}
\hline & & Frequency & Percent & Valid Percent & $\begin{array}{c}\text { Cumulative } \\
\text { Percent }\end{array}$ \\
\hline \multirow[t]{20}{*}{ Valid } & 1 & 2 & 1.3 & 1.3 & 1.3 \\
\hline & 2 & 7 & 4.7 & 4.7 & 6.0 \\
\hline & 3 & 10 & 6.7 & 6.7 & 12.7 \\
\hline & 4 & 11 & 7.3 & 7.3 & 20.0 \\
\hline & 5 & 21 & 14.0 & 14.0 & 34.0 \\
\hline & 6 & 8 & 5.3 & 5.3 & 39.3 \\
\hline & 7 & 9 & 6.0 & 6.0 & 45.3 \\
\hline & 8 & 19 & 12.7 & 12.7 & 58.0 \\
\hline & 9 & 5 & 3.3 & 3.3 & 61.3 \\
\hline & 10 & 10 & 6.7 & 6.7 & 68.0 \\
\hline & 11 & 8 & 5.3 & 5.3 & 73.3 \\
\hline & 12 & 9 & 6.0 & 6.0 & 79.3 \\
\hline & 13 & 7 & 4.7 & 4.7 & 84.0 \\
\hline & 14 & 8 & 5.3 & 5.3 & 89.3 \\
\hline & 15 & 6 & 4.0 & 4.0 & 93.3 \\
\hline & 16 & 5 & 3.3 & 3.3 & 96.7 \\
\hline & 17 & 3 & 2.0 & 2.0 & 98.7 \\
\hline & 18 & 1 & .7 & .7 & 99.3 \\
\hline & 20 & 1 & .7 & .7 & 100.0 \\
\hline & Total & 150 & 100.0 & 100.0 & \\
\hline
\end{tabular}

Table 8 Number of Employees

\begin{tabular}{|cc|c|c|c|c|}
\hline & Frequency & Percent & Valid Percent & $\begin{array}{c}\text { Cumulative } \\
\text { Percent }\end{array}$ \\
\hline Valid & 1 & 9 & 6.0 & 6.0 & 6.0 \\
& 2 & 38 & 25.3 & 25.3 & 31.3 \\
3 & 35 & 23.3 & 23.3 & 54.7 \\
4 & 27 & 18.0 & 18.0 & 72.7 \\
5 & 18 & 12.0 & 12.0 & 84.7 \\
6 & 6 & 4.0 & 4.0 & 88.7 \\
7 & 8 & 5.3 & 5.3 & 94.0 \\
8 & 4 & 2.7 & 2.7 & 96.7 \\
9 & 4 & 2.7 & 2.7 & 99.3 \\
11 & 1 & .7 & .7 & 100.0 \\
Total & 150 & 100.0 & 100.0 & \\
\hline
\end{tabular}




\section{APPENDIX-C}

\section{SURVEY QUESTIONNAIRE (English)}

Modern marketing techniques act as a catalyst for the selling activities of an entrepreneur: "An investigation of bakery and confectionery businesses in District Malir, Karachi, Pakistan".

\section{Dear Respondent:}

I, Ph.D. student of University of Karachi, Pakistan, am conducting a research on the aforementioned topic (An article) and I am in the process of data collection. You are requested to spare your few precious minutes for filling out the questionnaire in your hand. The information provided by you will be used purely for academic purpose and I will maintain confidentiality of your opinion expressed for this research. Thank you for cooperation and your time.

\section{SECTION ONE-BASIC INFORMATION}

Name:

Age: years

Gender: Male/Female/Other

Education: Under Matric/Matric/Intermediate/Graduate/Post Graduate

Nature of Business: Bakery \& Confectionery Business

Established Since: ___ years _ Number of employees: ___ persons

Business Name \& Address:

\section{SECTION-TWO-Modern Marketing Techniques}

Please encircle one number per statement to indicate your view towards the given questions, where 1 means that you strongly disagree, 2 means that you disagree, 3 means that you are neutral, 4 means that you agree, and 5 means that you strongly agree.

\begin{tabular}{|c|c|c|c|c|c|c|}
\hline \multirow[b]{2}{*}{1} & \multirow{2}{*}{$\begin{array}{l}\text { Entrepreneurial Selling Activities v/s Modern Marketing Techniques } \\
\text { Publicity affects the entrepreneurial selling activities. }\end{array}$} & \multicolumn{5}{|c|}{$\begin{array}{l}\text { Your } \\
\text { Choice }\end{array}$} \\
\hline & & 5 & 4 & 3 & 2 & 1 \\
\hline 2 & Banner displaying is the common method of publicity & 5 & 4 & 3 & 2 & 1 \\
\hline 3 & Banners and sign boards are considered the sufficient promotional activities. & 5 & 4 & 3 & 2 & 1 \\
\hline 4 & The front line workers must be equipped with the sales promotion techniques. & 5 & 4 & 3 & 2 & 1 \\
\hline 5 & The lack of sales promotion badly affect the business targets. & 5 & 4 & 3 & 2 & 1 \\
\hline 6 & Continuous advertisements are helpful in getting the selling advantage. & 5 & 4 & 3 & 2 & 1 \\
\hline 7 & The proper advertisement needs a reasonable marketing budget. & 5 & 4 & 3 & 2 & 1 \\
\hline 8 & The undesired advertisement does not generate the positive results. & 5 & 4 & 3 & 2 & 1 \\
\hline 9 & Social media is modern and easy access tool of marketing. & 5 & 4 & 3 & 2 & 1 \\
\hline 10 & SMS marketing is an effective marketing tool. & 5 & 4 & 3 & 2 & 1 \\
\hline 11 & Direct marketing is the easy way of marketing. & 5 & 4 & 3 & 2 & 1 \\
\hline 12 & Personal selling is very a very effective tool of marketing. & 5 & 4 & 3 & 2 & 1 \\
\hline
\end{tabular}

